\title{
New hypotheses about the origin of supernumerary chromosome segments in grasshoppers
}

\author{
J. P. M. Camacho and \\ J. Cabrero
}

\author{
Departamento de Biología Animal, Ecología y \\ Genética, Facultad de Ciencias, Universidad de \\ Granada, 18071 Granada, Spain.
}

The existence of euchromatic supernumerary chromosome segments which do not seem to represent repeated material cannot be explained by the current hypotheses (duplication or translocation) concerning the origin of extra segments. An hypothesis is proposed to explain the origin of the euchromatic extra segments distally located on the megameric $M_{6}$ chromosome of the species Omocestus bolivari and Chorthippus binotatus, namely that these segments represent a relic of an euchromatic region which formed part of the ancestral $\boldsymbol{M}_{6}$ chromosome of the gomphocerine grasshoppers. On the other hand, the absence of paracentromeric $C$-bands in some chromosomes of Chorthippus vagans and $C h$. brunneus could have been achieved by means of transformation of heterochromatin into euchromatin.

\section{INTRODUCTION}

Two mechanisms have been proposed for the origin of the supernumerary heterochromatic segments (White, 1954, 1973), both involving the repetition of chromosome segments. Firstly, by translocation from a chromosome of the standard complement or a $B$ chromosome. Secondly, by amplification of some part of the genome. Although the second hypothesis is accepted by the majority of authors (Shaw, 1971; John, 1973; Hewitt, 1979; Camacho et al., 1984), we have recently obtained some evidence for the origin of an extra segment in the grasshopper Oedipoda fuscocincta by translocation from the megameric $M_{9}$ chromosome (Camacho et al., 1986).

In this paper we analyse a series of supernumerary segments including two new forms of chromatin variation, one involving euchromatin and the other heterochromatin, whose origin needs to be explained by means of new hypotheses.

\section{MATERIALS AND METHODS}

Several natural populations of the grasshopper species Euchorthippus pulvinatus, Stenobothrus festivus, Omocestus raymondi, Chorthippus apicalis, $C h$. binotatus, $C h$. vagans and Ch. brunneus were sampled in the South of the Iberian Peninsula. The cytogenetic techniques employed for analysing these materials were the same as in Camacho et al. (1984).

\section{RESULTS}

Euchorthippus pulvinatus (fig. 1A)

While the $M_{6}$ chromosome carries a subdistally located $C$-band in the majority of Spanish populations analysed (Santos and Giráldez, 1982), one male from the Sierra de Alfacar (Granada) was heterozygous for the presence/absence of such $C$-band. On the other hand, the $S_{8}$ is frequently polymorphic for a supernumerary segment located proximally and darkly $C$-banded (Santos, 1980; Riva et al., 1984). We have found it in one out of 13 females analysed from Maitena (Granada).

\section{Stenobothrus festivus (fig. 1B)}

The $M_{7}$ and $S_{8}$ chromosomes may carry distal supernumerary segments which $C$-band darkly, although that on the $M_{7}$ is much larger than that on the $S_{8}$.

\section{Omocestus raymondi (fig. 1C)}

This species shows variation for the size of the interstitial $C$-band in the $X$ chromosome which 
coincides with the location of the nucleolar organiser region in this species (Cabrero and Camacho, 1986b). Furthermore, there was variation for the presence of two types of darkly $C$ banded extra segments located distally on the $M_{7}$ chromosome.

\section{Chorthippus apicalis (fig. 1D)}

A darkly $C$-banded supernumerary segment located distally on the $M_{7}$ chromosome was found in Alcalá la Real population with the following karyomorphic frequencies: $4 \mathrm{BB}, 8 \mathrm{Bs}$, 1 ss.

\section{Chorthippus binotatus (fig. 1E)}

We have found eight different supernumerary segments in Spanish populations of this species (Cabrero et al., 1986). Here we will mention only the euchromatic segment located distally on the $M_{6}$ chromosome.

\section{Chorthippus vagans (fig. 1F)}

In this species, we have found $C$-band variation in three chromosome pairs: $L_{3}, M_{4}$ and $M_{5}$. Some $L_{3}$ chromosomes possess an interstitial extra $C$ band in their short arm while some $M_{4}$ and $M_{5}$ chromosomes lack the paracentromeric $C$-band.

\section{Chorthippus brunneus (fig. 1G)}

The majority of populations analysed were polymorphic for $C$-band variations and supernumerary chromosome segments. With the single exceptior. of the $L_{3}$, all remaining chromosomes show some type of variation. A more detailed examination of such a complex polymorphism will be made in a separate paper. The variations in heterochromatin found in this species can be classified into three types: (a) variation for the size of paracentromeric $C$-bands in the $L_{1}$ and $L_{2}$ chromosomes, (b) amplification of $C$-bands in the $L_{2}$ associated with a NOR, $M_{7}$ and $S_{8}$ chromosomes, and (c) additional $C$-bands, including small $C$-bands located interstitially on the $X, M_{4}$ and $M_{5}$ chromosomes, and larger $C$-bands on the $M_{4}, M_{5}$ and $M_{6}$ chromosomes.

\section{DISCUSSION}

The amplification hypothesis could explain the origin of the majority of supernumerary heterochromatic chromosome segments analysed
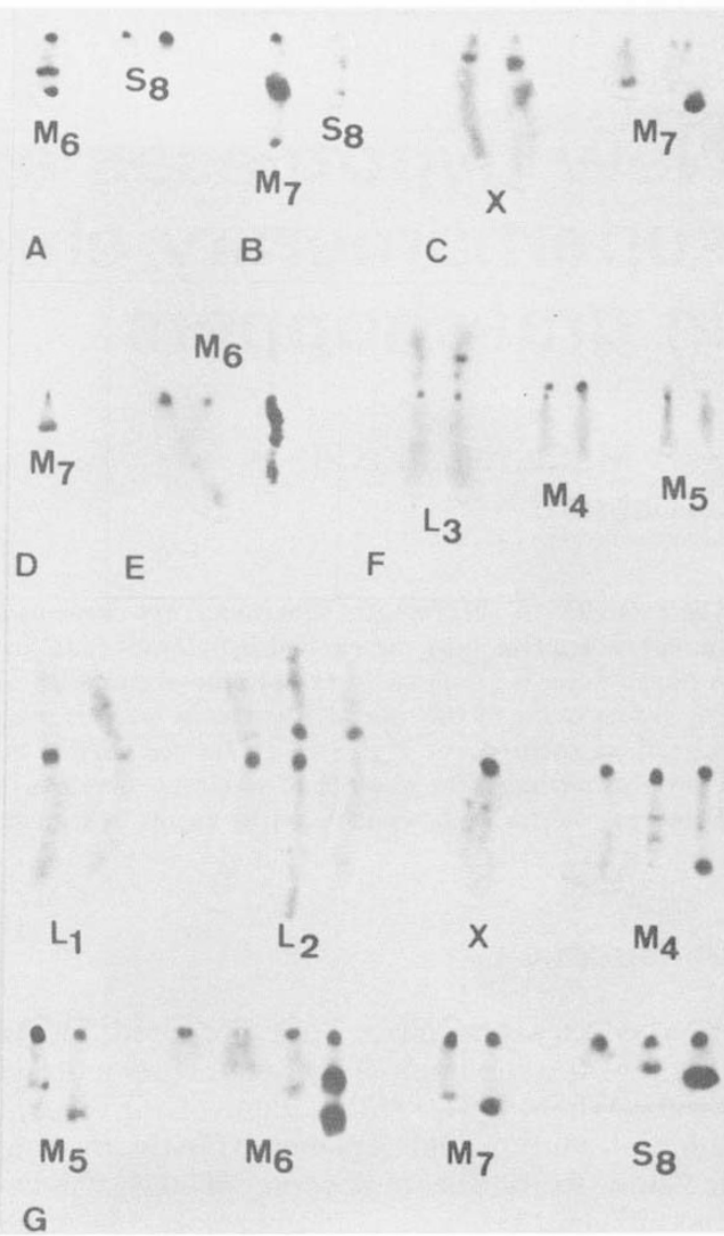

Figure 1 Supernumerary segments and $C$-band variations in gomphocerine grasshoppers. (A) Euchorthippus pulvinatus: unequal $M_{6}$ bivalent and heteromorphic $S_{8}$ pair. (B) Stenobothrus festivus: unequal $M_{7}$ and $S_{8}$ bivalents. (C) Omocestus raymondi: heteromorphic $X$ chromosomes from a female embryo, $M_{7}$ chromosome with a small distal extra segment and $M_{7}$ bivalent with an unsegmented member and the other carrying a large extra segment. (D) Chorthippus apicalis: $M_{7}$ chromosome with a distal extra segment. (E) Chorthippus binotatus: euchromatic extra segment distally located on $C$-banded (left) and silver stained (right) heteromorphic $M_{6}$ bivalents. (F) Chorthippus vagans: $C$ band variations in $L_{3}, M_{4}$ and $M_{5}$ chromosomes. Note the presence in the $L_{3}$ on the right of an extra $C$-band beyond the interstitial $C$-band on the short arm, and the absence of paracentromeric $C$-band in $M_{4}$ and $M_{5}$ homologues on the right. (G) Chorthippus brunneus: supernumerary segments and $\mathrm{C}$-band variations in chromosomes from neuroblast embryo mitoses. $L_{1}$ : variation in size of paracentromeric $C$-band. $L_{2}$ : variation for the size of interstitial $C$-band on short arm and for presence or absence of paracentromeric $C$-band. $X$ : interstitial extra $C$-band. $M_{4}$ : interstitial extra $C$-bands and subdistal extra segment. $M_{5}$ : interstitial and distal extra $C$-bands. $M_{6}$ : from left to right, basic chromosome, one lacking paracentromeric $C$-band, one carrying a grey extra segment and one possessing two darkly $C$-banded extra segments. $M_{7}$ : variation for the size of the distal $C$-band. $S_{8}$ : basic (left) and segmented chromosomes. 
in this report, but it is especially consistent with the amplification of pre-existing $C$-bands observed in the $S_{8}$ of E.pulvinatus, the $X$ of O.raymondi and the $L_{2}, M_{7}$ and $S_{8}$ of Ch.brunneus. When an heterochromatic supernumerary segment is located in a chromosome region which is euchromatic in its partner chromosome, the amplification hypothesis needs to be coupled with the heterochromatinisation of the duplicated regions (John, 1973). However, two other types of chromatin variation found in our investigation seem to have arisen by other mechanisms, namely the disappearance of paracentromeric $C$-bands and the existence of euchromatic extra segments. On the one hand, the paracentromeric $C$-bands are absent from some chromosomes of Ch.vagans and Ch.brunneus. Because the presence of paracentromeric $C$-bands is the norm in gomphocerine chromosomes (Cabrero and Camacho, 1986a) and given that there is no change in morphology or size of these chromosomes (as would be expected in the case of a deletion), we propose that these paracentromeric $C$-bands have been lost by means of a process of transformation of heterochromatin into euchromatin, similarly to that reported for the paracentromeric $C$-bands in the neo-Y chromosome of the grasshopper Stenacatantops angustifrons (King and John, 1980). On the other hand, the existence of euchromatic extra segments in the $M_{6}$ chromosomes of Chorthippus binotatus (this paper) and Omocestus bolivari (Camacho et al., 1984) contradicts all the existing hypotheses for the origin of extra segments. Although both extra segments are slightly different from one another in meiotic behaviour (that in Ch.binotatus associates distally with the unsegmented homologue, and that in O.bolivari does not show such association) both are similar in being euchromatic in nature. So, if they were composed of repeated chromosome material (such as would be expected from an origin by duplication or translocation), they must have been heterochromatinised like other chromosome repetitions (such as polysomic chromosomes) are in both species (Viseras and Camacho, 1984; Cabrero, 1985). The fact that the euchromatic extra segments in both species occupy a similar position (distal) in the same chromosome (the megameric $M_{6}$ ) seems to indicate that they could actually be a relic of an euchromatic region which formed part of the ancestral $M_{6}$ chromosome of the gomphocerine grasshoppers, a region which presumably has been lost in species other than O.bolivari and Ch.binotatus.

\section{REFERENCES}

CABrero, J. 1985. Estudios citogenéticos en saltamontes de la subfamilia Gomphocerinae: Heterochromatina, reordenaciones cromosómicas y actividad nucleolar. Tesis Doctoral, Universidad de Granada.

CABRERO, J. AND CAMACHO, J. P. M. 1986a. Cytogenetic studies in gomphocerine grasshoppers. I. Comparative analysis of chromosome $C$-banding pattern. Heredity, 56, 365-372.

CABRERo, J. AND CAMACHO, J. P. M. 1986 b. Cytogenetic studies in gomphocerine grasshoppers. II. Chromosomal location of active nucleolar organizing regions. Can. J. Genet. Cytol., 28, 540-544.

CABRERo, J., NAVAS-CASTILlo, J. AND CAMACHO, J. P. M. 1986. Effects of supernumerary chromosome segments on the activity of nucleolar organiser regions in the grasshopper Chorthippus binotatus. Chromosoma, 93, 375-380.

CAMACHO, J. P. M., NAVAS-CASTILlo, J. AND CABRERO, J. 1986. Extra nucleolar activity associated with presence of a supernumerary chromosome segment in the grasshopper Oedipoda fuscocincta. Heredity, 56, 237-241.

CAMACHO, J. P. M., VISERAS, E., NAVAS, J. AND CABRERO, J. 1984. $C$-heterochromatin content of supernumerary chromosome segments of grasshoppers: detection of an euchromatic extra segment. Heredity, 53, 167-175.

HEWITT, C. M. 1979. Grasshoppers and crickets. Animal Cytogenetics 3, Insecta 1 Orthoptera. Gebrüder Borntraeger, Berlin-Stuttgart, 170pp.

JOHN, B. 1973. The cytogenetic systems of grasshoppers and locusts. II. The origin and evolution of supernumerary segments. Chromosoma, 44, 123-146

KING, M. AND JOHN, B. 1980. Regularities and restrictions governing $C$-band variation in Acridoid grasshoppers. Chromosoma, 76, 123-150.

RIVA, E., FOX, D. P. AND SANTOS, J. L. 1984. Chiasma frequency and distribution in the presence and absence of supernumerary chromosome segments in the grasshopper Euchorthippus pulvinatus gallicus. Heredity, 53, 101-106.

SANTOS, J. L. 1980. Variación de la heterochromatina constitutiva en el cariotipo de los Acridoidea y su efecto en el comportamiento cromosómico en meiosis. Tesis Doctoral, Universidad Complutense de Madrid.

SANTOS, J. L. AND GIRALDEZ, R. 1982. C-heterochromatin polymorphism and variation in chiasma localization in Euchorthippus pulvinatus gallicus (Acridide, Orthoptera). Chromosoma, 85, 507-518.

SHAW, D. D. 1971. the supernumerary segment system of Stethophyma II. Heterochromatin polymorphism and chiasmata variation. Chromosoma, 34, 19-39.

VISERAS, E. AND CAMACHO, J. P. M. 1984. Polysomy in Omocestus bolivari: endophenotypic effects and suppression of nucleolar organizing region activity in the extra autosomes. Can. J. Genet. Cytol., 26, 547-556.

White, M. J. D. 1954. Animal Cytology and evolution. $2^{a} \mathrm{ed}$. Cambridge Univ. Press, london.

WHITE, M. J. D. 1973 Animal cytology and evolution. $3^{a}$ ed. Cambridge Univ. Press, London and New York. 